\title{
Assessing the Impact of Deliberative Democratic Initiatives at the Local Level: A Framework for Analysis
}

Administration \& Society 2019, Vol. 5I(5) 749-769

(C) The Author(s) 2018

Article reuse guidelines: sagepub.com/journals-permissions DOI: I0.II77/00953997/8760588 journals.sagepub.com/home/aas

\section{Ank Michels' and Harmen Binnema'}

\begin{abstract}
Although deliberative reforms have been proposed to strengthen democracy, little is known about their impact on politics, public policies, and society. This article develops a framework to systematically assess this impact, differentiating between direct and indirect forms of impact. We apply this framework to two cases of deliberative citizens' summits in the Netherlands. Our analysis reveals that these summits have a limited direct impact on local politics and policy making, but a relatively strong indirect impact on the local community. The article also discusses some conditions that mediate the impact of the forum.
\end{abstract}

\section{Keywords}

deliberative forums, citizen participation, local governance, political impact, social impact

\footnotetext{
IUtrecht University, The Netherlands

Corresponding Author:

Harmen Binnema, School of Governance, Utrecht University, Bijlhouwerstraat 6, 35 I I ZC Utrecht, The Netherlands.

Email: h.a.binnema@uu.nl
} 


\section{Introduction}

A large body of research has shown declining levels of satisfaction with the institutions and processes of representative democracy (Dalton, 2014; Hibbing \& Theiss-Morse, 1998; Kaase \& Newton, 1995). Various researchers have gone so far as to refer to a democratic deficit, regarding democratic organizations, institutions, and governments as falling short of fulfilling the principles of democracy in their practices or operation (Nabatchi, 2010). As a result, many scholars and opinion leaders have proposed participatory and deliberative reforms to strengthen democracy and complement its existing forms (Cain, Dalton, \& Scarrow, 2006; Inglehart \& Welzel, 2005; Skocpol, 2003; Van Reybrouck, 2013).

Deliberative forums may strengthen democracy, first, by giving people a voice in shaping and informing policy and in political decision making. This political impact adds to existing forms of representative democracy (Goodin $\&$ Dryzek, 2006). Second, in a more indirect way, these forums could encourage citizenship and enhance social capital (Bryson, Quick, Schively Slotterback, \& Crosby, 2013; Fung, 2015; Putnam, 2000), which we label social impact. Although the number of studies on deliberative democratic innovations is growing (e.g., Fung, 2015; Grönlund, Bächtiger, \& Setälä, 2014), the focus in most studies is on the outcomes internal to participation or deliberation, such as the quality of deliberation or the satisfaction of participants with deliberation. As yet, we know very little about the democratic macro-effects (Pogrebinschi \& Ryan, 2017), that is, the impact of deliberative processes on politics, public policies, and the social community. A systematic and consistent approach to evaluate these macro-effects is lacking, which makes it hard to draw conclusions about impact and to compare deliberative forums and their outcomes.

This article contributes to a systematic analysis of democratic impact of deliberative forums in two ways. First, it develops a conceptual framework that not only differentiates between political and social impact but also refines these two types of impact by looking at instrumental, conceptual, and strategic aspects. Second, our contribution lies in the application of this framework to two cases of deliberative citizens' summits that were held in the Netherlands in 2014. Based on our conceptual and empirical discussion, we identify five conditions that mediate the impact of the forum: (a) the institutional design, (b) the embeddedness in the political system, (c) the policy issue at stake, (d) the connection with civil society, and (e) the interaction between actors involved in the deliberative forum. 


\section{Assessing Impact}

Citizen participation can serve a large number of purposes. In their discussion of various designs for public participation, Bryson et al. (2013) identify, among others, the following: advancing social justice, enhancing the quality of policies, plans and projects, generating support for policies and their implementation, or enhancing the adaptive capacity for problem solving. In a similar vein, Goodin and Dryzek (2006) provide a broad catalog of impacts of public engagement innovations, ranging from direct impact on policy to more indirect effects such as confidence building or popular oversight. Impact or effects may be related to each of these objectives, so we need to specify exactly what is meant by impact of deliberative forums.

In this article, we are interested in the macro-effects of deliberative forums, that is, their impact on politics, public policies, and the social community. Hence, we move beyond the internal focus of much of the current deliberative democracy literature, shifting the attention to the actual impact: what is done with the outcomes after deliberation has taken place?

While the relatively scarce literature on impact tends to focus on political and institutional settings, we, by contrast, are also interested in the effects of deliberative forums outside of politics and policy making. This is related to the social impact we introduced earlier on, and it also fits with the objectives advanced by the organizers of deliberative forums. They regard the forums as a means for influencing policy making, but also for mobilizing and activating the local community. Finally, we refine our analysis of impact by making a distinction between instrumental, conceptual, and strategic impact and provide some empirical underpinning by applying this framework to two Dutch cases.

What does political and social impact mean for local democracy? Political impact concerns the impact of recommendations or proposals stemming from the deliberative forum in the political arena, that is, the local council and local administration. Social impact encompasses the effects in society at large, including the actions of civil society organizations and public debate. In addition, one can distinguish between (a) impact on the individual, the group, or the community; (b) substantive or procedural impact; and (c) impact in the short or the long term (Bryson et al., 2013, p. 30). We have captured these dimensions of impact by focusing on the mechanism by which the recommendations or proposals from the deliberative forums affect the recipients. This leads to a threefold categorization - instrumental, conceptual, and strategic (cf. Bekkers, Fenger, Homburg, \& Putters, 2004) - to refine the broader notions of political and social impact. Our framework for analyzing the different forms of impact is shown in Table 1. 
Table I. A Conceptual Framework for the Analysis of Impact of Mini-Publics.

\begin{tabular}{clll}
\hline & Instrumental impact & Conceptual impact & \multicolumn{1}{c}{ Strategic impact } \\
\hline Politics & $\begin{array}{c}\text { Translation of } \\
\text { recommendations } \\
\text { into decisions or } \\
\text { concrete actions of } \\
\text { decision makers }\end{array}$ & $\begin{array}{c}\text { Recommendations } \\
\text { become part of } \\
\text { a larger debate } \\
\text { about participation; } \\
\text { participation is put on } \\
\text { the political agenda }\end{array}$ & $\begin{array}{c}\text { (Recommendations of } \\
\text { mini-publics are used to } \\
\text { strengthen power of one } \\
\text { or some political actors } \\
\text { (e.g., by legitimizing } \\
\text { existing policy) }\end{array}$ \\
$\begin{array}{ccc}\text { Society } \\
\text { Translation of }\end{array}$ & $\begin{array}{c}\text { New and other forms } \\
\text { recommendations }\end{array}$ & $\begin{array}{l}\text { Recommendations } \\
\text { of participation }\end{array}$ & $\begin{array}{l}\text { derived from mini- } \\
\text { publics are used to }\end{array}$ \\
into concrete & develop & strengthen power of \\
actions of & & one or some individuals \\
individuals or & & or organizations \\
organizations in & & \\
the community & &
\end{tabular}

Instrumental impact occurs when recommendations find their way directly to decision making (actually making policy, as it is called by Goodin \& Dryzek, 2006), implementation or concrete actions. Political impact means that the local council responds to the forum's proposals. The recommendations set the agenda of the local council, they are discussed in the local council, and are given follow-up. In terms of social impact, the recommendations evoke responses in terms of actions of groups, organizations, or individuals in the local community.

Conceptual impact, the second form of impact, refers to a more indirect effect of recommendations. Recommendations are part of a complex process of interaction and discourse between various actors. Conceptual impact implies a gradual change in orientation or insight with respect to participation and citizen involvement due to a shift in knowledge, opinions, and attitudes. This gradual change can manifest itself in political impact or social impact. Political impact is comprised of two elements: First, it means that the concept of "participation" is on the political agenda as a result of the experience with the deliberative forum. Second, the attitudes and work processes of the local council and administration become more responsive to participation and the wishes of citizens. Social impact takes the form of the emergence of new forms of participation and actions, as well as a broader "participation movement."

The third form of impact is strategic impact. Policy making is also subject to different and often conflicting goals and interests (Stone, 2011), and policy decisions are the outcome of this permanent conflict. From this point of view, 
recommendations are used either to strengthen one's own position or to weaken the position of another actor. To establish the strategic political impact of deliberative forums, we look at the extent to which experiences with the mini-public or the recommendations are used to defend certain decisions or to attack the ideas of other politicians. Similarly, strategic social impact implies that recommendations are used to support specific societal actors or to oppose others.

\section{Deliberative Forums and Their Effects}

In recent decades, there has been a growing interest in the use of deliberative forums or "mini-publics," such as citizens' forums or citizens' juries, consensus conferences, and deliberative polling. Although the designs differ, they also share a number of common characteristics (Ryan \& Smith, 2014, p. 20; Smith, 2009). Deliberative mini-publics are first and foremost characterized by structured deliberation, enabled by independent facilitators. A deliberative process involves dialogue and the exchange of arguments in small and diverse groups of citizens. It assumes free public reasoning, equality, inclusion of different interests, and mutual respect. A second key element is the participation of a broadly inclusive subgroup of an affected population representing a wide variety of opinions. Often, sortition is used as the selection mechanism to obtain a diverse body of participants. To achieve the goal of diversity, other mechanisms may be used as well, such as targeting specific groups known to be often underrepresented in participation processes (Ryan \& Smith, 2014).

Empirical research on the macro-effects of deliberative forums is scarce. What evidence there is concerns the political and policy impact, and suggests that the impact of deliberative forums tends to be low. According to Goodin and Dryzek (2006, p. 7), there are very few examples to be found in which deliberative forums or mini-publics are formally empowered as part of a decision-making process. An exception is the much-vaunted Canadian British Columbia Citizens' Assembly (Smith, 2009, pp. 88-93). In most cases, deliberative forums are not a part of the formal decision-making process, as becomes clear in the case of the Spanish citizen juries (Font \& Blanco, 2007), the Dutch citizens' forum on electoral reform (Van der Kolk, 2008), and the Belgian citizens' forum G1000 (Caluwaerts \& Reuchamps, 2016).

At the same time, there is scattered evidence that deliberative forums sometimes do have impact on policy decisions, even though they are not a formal part of the decision-making process (Font, Smith, Galais, \& Alarcon, 2015; Fung, 2015; Grönlund et al., 2014). Goodin and Dryzek (2006) point to instances of both failing mini-publics and successful mini-publics, 
thereby emphasizing different kinds of effects. This mixed picture is confirmed in many other studies (Hoppe, 2011; Olsen \& Trenz, 2016; Strandberg, 2015), at the local, national, and international level, and in a range of policy issues.

We can distinguish a number of conditions that mediate the impact of deliberative forums. First, some studies suggest that policy impact depends on the type of policy issue that is at stake. Impact is shown in cases where tangible issues, for example, infrastructure or city development, were being deliberated (Michels, 2011) and for redistributive policies (Pogrebinschi \& Ryan, 2017). Second, it is argued that the impact on policy making depends on the design of the mini-public: forums in which people meet each other on several occasions, rather than on a single day only, create more pressure on the policy-making process (Fung, 2006; Pogrebinschi \& Ryan, 2017). Also, studies show that consensus conferences in Denmark and local and regional planning cells in Germany have had some influence on policy making, whereas citizens' conferences have not (Caluwaerts \& Reuchamps, 2016; Flynn, 2009). Third, impact seems related to the connection with local politics (Caluwaerts \& Reuchamps, 2016; Hendriks, 2016; Tahvilzadeh, 2015) and local society (Ercan \& Hendriks, 2013). The more a deliberative forum is embedded in local politics or linked with existing citizen initiatives, the more likely that it will have an impact.

\section{Context, Cases, and Method}

In this article, we assess the political and social impact of two local citizens' summits, so-called G1000s, in the Netherlands. For this purpose, we use the framework that was introduced earlier on (Table 1). These G1000s were inspired by the national G1000 that was held in Belgium in 2011. This citizens' summit was organized by a group of citizens, among them the Flemish author David Van Reybrouck (2013), and was an answer to the political instability that Belgium was witnessing at that time. The aim of the Belgian summit was to empower citizens and to reach an agreement, something politicians were then unable to achieve (G1000, 2012).

The participants were randomly selected to have a representative group of people. About 600 people gathered together for a day of deliberations in the Belgian capital, Brussels. The G1000 was an outside challenger of Belgian politics; it was neither embedded in nor supported by the official institutions. The summit received much media attention, but after the G1000 had taken place, there was no political follow-up. A new government was formed that had no interest at all in the proposals of the G1000 (Caluwaerts \& Reuchamps, 2016). 
The Belgian experience with a citizens' summit involving a large number of people inspired many groups of citizens, politicians, and public officials in the Netherlands to organize a similar type of event. G1000s and similar citizens' summits have been organized in a number of cities and neighborhoods, of which the municipalities of Amersfoort and Uden were the two first ones. We selected these two cases to test our framework for two reasons. First, they explicitly shared a double aim: They wanted to have both an influence on the political and policy agenda and to formulate an agenda for citizens to take up as their own responsibility. These aims were reflected in two questions that were put to the participants during the summit: (a) What ideas would you wish to see achieved in your city during the next 4 years? and (b) How are you going to contribute to achieve these ideas? All G1000s worked with an open agenda, meaning that it was up to the participants to discuss the issues they deemed relevant. Second, they differed in the extent to which they were tied to and embedded in the political system. The G1000 in Uden was initiated and supported by local councillors. In contrast, the idea for a G1000 in Amersfoort came from a group of citizens. A forum that is initiated or explicitly supported by politicians, like that in Uden, is more likely to be taken seriously (for a similar argument, see Caluwaerts \& Reuchamps, 2016). We expect that the recommendations generated by such a forum are more likely to be heard, accepted, and followed by the established institutions.

The G1000 in Amersfoort was the first of its kind to be organized in the Netherlands. Amersfoort is a city of about 150,000 inhabitants that is located in the center of the Netherlands. The G1000 was held on March 22, 2014, and initiated by a group of citizens. After a random selection of participants through sortition among all inhabitants, 540 people accepted the invitation and took part, among them 450 lay citizens. By the end of the meeting, a top 10 of topics for the city of Amersfoort was generated.

Following the example of Amersfoort, Uden was the second city to organize a G1000. The municipality of Uden, which is an amalgamation between Uden and two surrounding villages (Volkel and Odiliapeel), has about 41,000 inhabitants and is located in the south of the Netherlands. The G1000 in Uden was initiated by a number of council members and the council secretary and was held on October 4, 2014. An open invitation was issued to all inhabitants aged 16 years and above to participate. To minimize the self-selection bias, specific groups known to be often underrepresented in participation processes, such as people with non-Western backgrounds, were targeted by using key persons in specific neighborhoods and distributing flyers in supermarkets or the mosque. All in all, 250 lay citizens took part, who selected 10 ideas by the end of the day, just like in Amersfoort. 
To analyze the impact of the deliberative citizens' summits in this study, we first provide a description of how they started, with a focus of the role of the local council and the local government prior to the start of the G1000. This description is based on documents and on interviews with council members, aldermen, mayors, civil servants, and organizers of the G1000s in Amersfoort and in Uden. We then analyze what has been the effect of the recommendations, both in the political field and in the local society, while differentiating between aspects of instrumental, conceptual, and strategic impact. In the analysis, we focus on the period immediately following the G1000 until May 2015.

With respect to political impact, the analysis is primarily based on interviews with 10 council members (five of whom from opposition parties), two council secretaries, two aldermen, three civil servants, and three G1000 organizers. We also used other sources, such as political agendas of the council, newspaper articles, newsletters, and documents published by the local G1000 organizers. With respect to social impact, we used newsletters and websites of the G1000 organizations about the activities of the working groups that ensued from the G1000.

In particular, we look at what has been done with the recommendations formulated during the G1000, in the light of the following:

- Did the recommendations set the agenda of the local council? Were the recommendations discussed in the local council? and What was the actual follow-up of the recommendations politically and socially (instrumental impact)?

- Was participation as such discussed by the local council? Did the attitudes and work processes of the local council and administration change? and Did it lead to new forms of participation and actions in the local community (conceptual impact)?

- Were recommendations used to defend or oppose particular interests (strategic impact)?

\section{How It Started}

\section{Amersfoort}

Amersfoort already had a tradition of citizen initiatives prior to holding the G1000. The council term 2010-2014 had been characterized by considerable political instability, with a number of policy issues causing political and societal unrest, and various changes occurring in the composition of the local coalition government. As a result, both politicians and civil servants had 
become rather inward looking, which led to a feeling among many that the local authorities were very much at a distance. To reconnect with the local administration, a group of citizens initiated Het Nieuwe Samenwerken (HNS, The New Collaboration) at the end of 2011. Their diagnosis for a closer cooperation between citizens and council members read as follows (https://bewoners033.n1/):

- the council seemed to adopt a passive role rather than actively participating in a dialogue with citizens;

- policy making was mainly unidirectional and not transparent enough;

- the outcome of interactive policy making or other forms of citizen consultation was often not taken seriously;

- citizens had lost interest and no longer participated.

It is fair to say that HNS more or less paved the way for the G1000. The start of the G1000 initiative can be traced back to the autumn of 2013 when the G1000 Foundation was established, which boasted three board members, none of whom was a politician or civil servant. Initially, the G1000 was set up with very little involvement of politicians, although senior civil servants, the mayor, and the council secretary supported the idea in the background. Some of the organizers clearly believed that this should be a bottom-up citizen initiative, as an alternative to electoral, representative democracy. In particular, through meetings that were organized by a former alderman who very much embraced the G1000 philosophy, local politicians became more involved. However, the role of these politicians was limited to giving advice and being informed; the actual organization was in the hands of the G1000 Foundation and a handful of volunteers.

\section{Uden}

Very soon after the municipal elections of 2014, the council secretary took the initiative to hold a conference, with as central topic the role of the council vis-à-vis society. As was the case in Amersfoort, the local council in Uden was viewed as being inward looking and aloof, focusing primarily on the city hall agenda and involving citizens only to a limited extent. The conference was meant to provide a fresh start, also given the new composition of the recently elected council. During this conference, one of the important issues on the table was how to improve the connection between citizens and council members. Many council members became enthusiastic about the idea of organizing a G1000 in Uden. Only one of the local political parties objected to the idea — and this party has remained skeptical or outright negative ever 
since (interview local councillor). One of the other parties was slightly hesitant but was willing to give the G1000 a chance.

In contrast with Amersfoort, a number of local politicians and the council secretary in Uden were quite active in organizing the G1000. In the background, the mayor also supported the idea, and he was also instrumental in providing financial support. The involvement of both the civil service, the mayor and the members of the municipal council, shows that the Uden G1000 was more tied to the political system than in Amersfoort.

\section{Political Impact}

\section{Political Instrumental Impact}

Amersfoort. In the final round of the G1000, 10 proposals were selected by the participating citizens through voting. Together, these proposals would form the "Agenda for Amersfoort." One concerned the organization of a G1000 at the neighborhood level, a proposal that was indeed implemented some months later in the neighborhoods of Kruiskamp (concluded in January 2015) and Zielhorst (concluded in January 2016). Four of the proposals pertained to the environment, green areas or sustainability, while another four focused on civil society. These four proposals called for better communication about what went on in the neighborhood, making new connections, doing things together, and looking after each other. Finally, one proposal concerned local safety, with a focus on getting to know the neighbors better and more social monitoring. For some of these proposals, little was required of local government and the local council; others, however, would involve policy changes, and hence commitment from political parties.

The 10 proposals were presented to the mayor by the G1000 chairman, who added that he hoped this Agenda would be picked up by the local council. Right before this closing ceremony, all G1000 participants had been invited to "adopt" one of the proposals and to form a working group that would further develop the idea and put it into practice. This may also explain why the mayor was rather reluctant to simply pass the Agenda on to the local council, but instead emphasized that it was up to the city to take action.

More than a year after the G1000 had taken place in Amersfoort, it became clear that the topics of the "Agenda for Amersfoort" never made it onto the council agenda nor onto the agenda of the Municipal Executive. Some topics turned out to be overlapping with existing local policy, whereas others did not require involvement of the local government. Moreover, the councillors were hesitant to give a special status to the G1000, as compared with various other 
forms of input by citizens. For these reasons, we argue that the instrumental impact of the G1000 Amersfoort was limited.

Uden. Just as in Amersfoort, a voting round took place at the end of the afternoon to select the 10 "best" proposals. During the day, participants also had to briefly present their proposals and vote and select them in small groups at the round tables. As a result, most of the proposals in the Uden top-10 were quite concrete, as compared with the more abstract wording in Amersfoort. They concerned topics such as more safety for cyclists and pedestrians, accessibility of the town center to visually disabled people, and the preservation of the public library. More than half of the proposals required action by the local government, whereas other proposals concerned activities that citizens could organize themselves. The latter included initiatives aimed at counteracting loneliness or achieving a better match between supply and demand for small services.

In other words, the proposals in Uden were closer to the policy agenda, both in how they were formulated and who they called upon. Some politicians were under the impression that this was how the G1000 was framed at the start of the day. They felt they could not afford to ignore the outcomes of the G1000, but had to act upon these (interviews local councillors). It should be said, however, that some of the proposals were already part of existing local policy, or policy being developed. For example, the city administration was already working on a traffic and infrastructure plan to improve the safety and infrastructure for cyclists, in which the ideas about cycling from the G1000 working group could easily be integrated. Therefore, the better infrastructure for cyclists was not the result of the council or the alderman's choosing to follow the recommendations of the G1000.

Although council members were involved in organizing the G1000, in the end, they did not want the proposals of the G1000 to be seen as a "wish list" for the local council. Similar to their fellow councillors in Amersfoort, they felt no obligation to render account for their actions regarding the top 10 of the G1000 (interview local councillor). Although the local G1000 organization did share the results and progress made by the working groups at a number of council meetings, the council did not put the recommendations from the G1000 on the municipal agenda. The instrumental impact of the G1000 Uden should therefore be considered limited.

\section{Political Conceptual Impact}

Amersfoort. Most of the politicians we interviewed were enthusiastic, not only about the concept of a G1000 but also about the way it actually worked 
out during the day. They found the participating citizens willing to share their ideas and engage with others in a positive and constructive way. Some of the politicians also maintained that the G1000 offered more room to look beyond the narrow self-interest so often encountered in formal settings, such as a public hearing or when citizens have their say at the start of a council meeting (interview local councillor). Even the council members who started out skeptical in advance changed their minds after observing the enthusiasm and energy of the G1000.

Although the instrumental political impact was found to be limited, the "spirit of the G1000," that is, the projection of this type of citizen involvement in several policy areas, survived. Many local councillors were enthusiastic about the possibility to discuss local topics in a setting similar to the G1000 (interview local councillors). They also felt that in a couple of years another G1000 should be held to renew the Agenda for Amersfoort. However, the idea put forward by the G1000 platform to organize a G1000-like meeting with citizens, local entrepreneurs, and councillors about cutbacks and the core tasks of the municipality failed to take hold.

Other politicians were more skeptical mainly because they preferred to rely on the role of political parties and the existing institutions of representative democracy. The alderwoman pointed at the risk of the G1000 becoming "the only thing in town," to the detriment of Amersfoort's rich tradition of various kinds of citizen initiatives. All in all, we qualify the conceptual impact of the G1000 Amersfoort as moderate.

Uden. Although the instrumental impact was also found to be limited in Uden, the G1000 was considered very valuable as a bottom-up process that put citizens in charge, and who showed themselves capable of formulating realistic and sensible ideas. As was the case in Amersfoort, a number of councillors were worried that citizens would present utopian or very expensive ideas, but they were happy to admit they had been proven wrong (interview local councillors). Others had been more optimistic from the start, arguing that citizens could provide the kind of practical expertise that councillors and civil servants, who focus on academic and professional knowledge, are often lacking. Almost all the politicians and civil servants who attended the meeting were enthusiastic about the atmosphere, the quality of the discussions, and the level of citizen engagement. This was also true for the council members who had shown some hesitation during the conference of the council at which the idea of organizing the G1000 was born.

However, what can be established is that, even though politicians and civil servants were involved in some of the working groups, the functioning of the local council has remained largely the same. The focus is on city hall, the 
traditional policy cycle, and the interaction with other political parties. The councillors are still struggling to find new ways of interacting with citizens. The same holds for the mayor and alderman, although the board does embrace the philosophy of G1000. We consider the conceptual impact of the G1000 Uden to be moderate.

\section{Political Strategic Impact}

Amersfoort. Some participants had the impression that the date of March 22, 2014, soon after the elections, was specifically chosen to influence the agenda of the council, and in particular the political parties that were negotiating the coalition agreement (interview council secretary). Others argued that it was mere coincidence and that this was not a strategic decision: The building where the G1000 would take place happened to be available that day (interview local councillors). No matter which of these versions is true, the outcomes of the G1000 did not play a role in the negotiations.

We also did not find any strategic impact - in the sense of political parties using specific outcomes ("shopping") to promote their own political agenda. In the interviews, local councillors emphasized the abstract nature of many of the G1000 proposals, with a number adding that they preferred the ideas of their own election program.

Uden. In this case as well, we found no evidence of strategic impact. For those issues in which government intervention was required, the G1000 outcomes were not invoked by the various political parties to promote their own political agenda. Moreover, according to councillors and members of the College of Mayor and Aldermen, for most of the proposals, which the aldermen present to the council, the question of whether or not citizens have been involved or consulted in the preparation of these proposals hardly comes up. This has not changed very much since the G1000.

\section{Social Impact}

\section{Social Instrumental Impact}

Amersfoort. After the Agenda for Amersfoort had been selected, working groups composed of citizens, civil servants, and politicians were formed. This idea looked good on paper, but came to very little in practice. Some themes were merged into one group; other groups only met a couple of times, but then gradually dried up. Part of this was already visible at a conference in September 2014, where the number of active citizens had decreased 
substantially, compared with the G1000 in March. In January 2015, the team that coordinated all the working groups decided to disband.

However, there are two exceptions that should be mentioned: the G1000 that was organized in the neighborhood Kruiskamp, followed by Zielhorst a year later, and a group that developed a monthly award for fellow citizens who do something special for their neighborhood. Also, individual members of the working groups connected with existing neighborhood initiatives. After a year, the overall conclusion was that most of the plans failed to be put in practice: The instrumental impact was limited.

Uden. Most of the proposals that came up in the G1000 in Uden were quite concrete, and citizens clearly felt a sense of ownership of the proposals. Many people became active as a result although the enthusiasm of the first months after the G1000 was found to have waned. Originally, more than 100 participants had enrolled in the working groups, though we have to add that several of them were no longer active a year later.

The follow-up of the working groups was stimulated by the establishment of the Kantelhuis (Tilting house) in the city center, where citizens can meet to discuss new ideas and the progress of the various themes. The working group on energy neutrality joined forces with an energy citizen cooperation. Moreover, some of the groups stemming from the G1000 merged with groups from Udenaar de Toekomst, an existing platform for citizen initiatives. All in all, there seems to be a rather strong instrumental impact of the G1000 held in Uden.

\section{Social Conceptual Impact}

Amersfoort. Although plans were made to hold G1000s in a number of neighborhoods in Amersfoort, we were not able to establish a link between the G1000 and other forms of citizen participation in Amersfoort, apart from individuals who are active in various platforms. From that perspective, the conceptual impact is limited, although it is clear that the G1000 fits in a tradition of citizen initiatives in Amersfoort.

Uden. In Uden, the G1000 appears to have given rise to a somewhat larger number of activities than in Amersfoort. One example is the "Learning Café," in which citizens share experiences and expertise, and where discussions about recent events take place. This café does not have a fixed schedule, but there are numerous activities, often in cooperation with civil society organizations, and closely related to the aforementioned Kantelhuis (website G1000 Uden). Hence, there is a moderate conceptual impact of the G1000 Uden. 


\section{Social Strategic Impact}

Neither in Amersfoort nor in Uden have there been examples of individuals or organizations using the outcome of the G1000 to support particular actors or to oppose others. We therefore conclude that it has not had any strategic impact in the local community.

\section{Discussion}

Deliberative innovations are often seen as a way to strengthen democracy and complement the existing forms of democracy (Cain et al., 2006; Grönlund et al., 2014; Inglehart \& Welzel, 2005; Nabatchi, 2010). Focusing on the macro-effects of deliberative processes, deliberative forums may strengthen democracy in two ways: directly, by giving people a voice in decision making (political impact), and in a more indirect way, by encouraging citizenship and social capital (social impact). In addition, we distinguish between instrumental, conceptual, and strategic impact. Combining these two categorizations, we arrived at a framework for measuring impact, which we applied to two mini-publics in the Netherlands, the G1000s held in Amersfoort and Uden.

Our findings, which are summarized in Table 2, show that the political instrumental impact of the G1000, that is, the degree to which recommendations were actually translated into decisions or concrete actions of decision makers, was rather low. Strategic impact, both political and social, was absent. Our findings were somewhat different where political conceptual impact is concerned. The spirit of the G1000 was alive in Amersfoort and in Uden, as the majority of local politicians embraced the G1000 philosophy. Both cities consider this a valuable type of citizen involvement and have expressed a willingness to use this approach to discuss other local topics as well. Particularly in Uden, even stronger effects of the proposals of the citizens' summits were found in the local community at large (social instrumental and conceptual impact). A large number of citizens became active and several initiatives originated from the proposals that were the outcome of the G1000. Also, some new forms of initiatives and participation developed.

What, then, are the implications of these findings? Our approach points to five factors that may contribute to the type and degree of impact: (a) the institutional design, (b) the embeddedness in the political system, (c) the policy issue, (d) the connection with the existing civil society, and (e) the interaction between actors.

An important aspect of the institutional design is that both citizens' summits were one-off forums. One could argue that longer lasting forums in which people meet each other on several occasions, rather than on a 


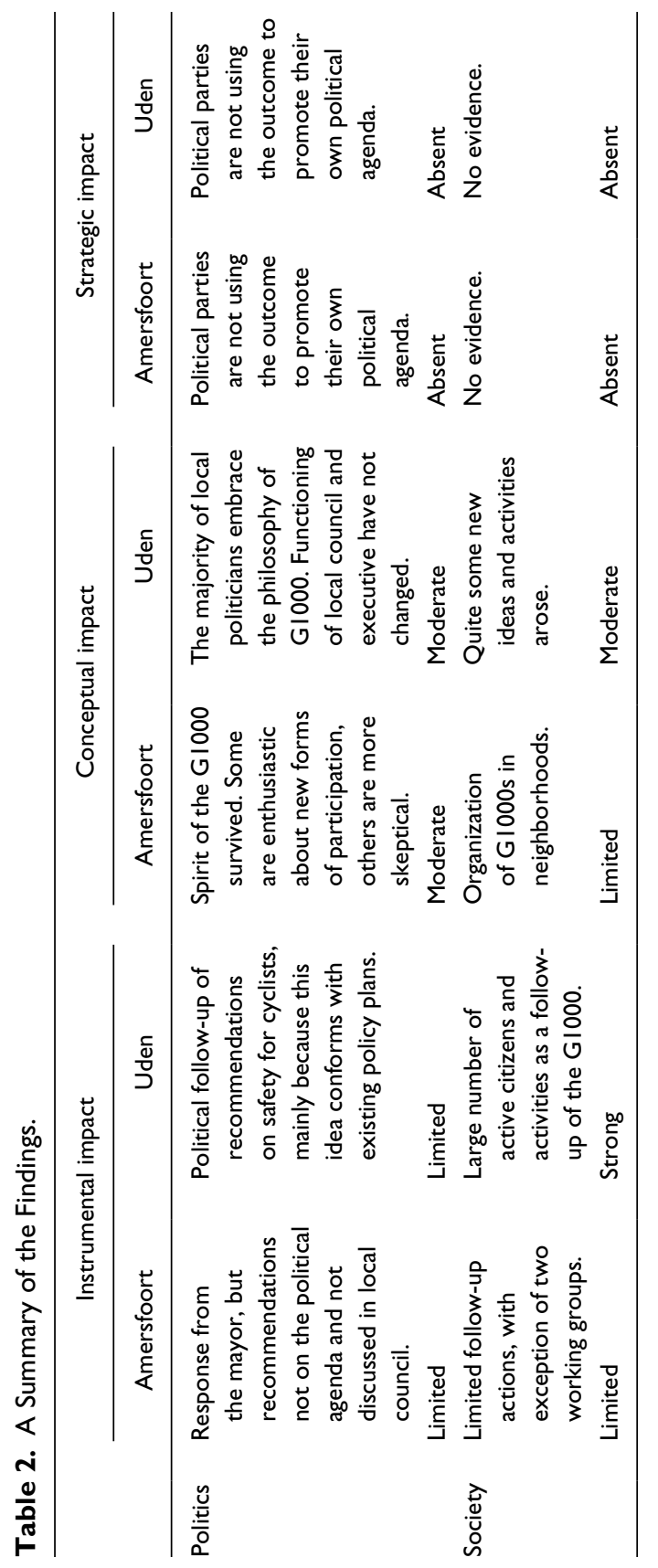


single day only, create more pressure on the policy-making process, and thus have more political instrumental impact (cf. Pogrebinschi \& Ryan, 2017). The outcome of these one-off forums could easily be put aside by politicians, while participatory processes held repeatedly over time may experience institutionalization and legitimacy in the eyes of politicians, adding to their impact.

A second factor is the embeddedness in the political system. This relates to a growing strand in the literature on deliberative democracy, which no longer sees mini-publics as isolated spaces with ideal conditions for respectful and inclusive reason-giving, but instead emphasizes the importance of a mini-public's embeddedness in the broader deliberative system (Curato \& Böker, 2016). We argue that the recommendations generated by a forum that is initiated or explicitly supported by politicians would more likely be heard, accepted, and followed by the established institutions and thus have political impact (Caluwaerts \& Reuchamps, 2016). However, we found that even in the case of Uden, where the citizens' summit was initiated and supported by the local council, the recommendations of the G1000 had little impact. They were not discussed in any political forum nor did they bring about any change in existing policies. This may have to do with the fact that both Uden and Amersfoort aimed at creating political and social impact at the same time. This double aim seems to have created some ambiguity about the status of the forum: Was it primarily a political forum to influence policy makers or a forum for the community to create citizen involvement?

A third factor relates to the topic of the deliberations. Previous studies suggested that political impact is related to specific types of issues (Curato \& Böker, 2016; Michels, 2011; Pogrebinschi \& Ryan, 2017). Characteristic of the cases in this study, however, is that the topic of the deliberations was not defined before the start of the meeting. By using an open agenda, the aim was for the participants to decide the topics and to discuss whatever they considered relevant. This seems to have diminished the political impact of the deliberation results: It led to rather abstract and unspecified proposals. Some of these turned out to be part of existing policy already, which made it easy for the local council to ignore them. This may also explain why we found no evidence of any strategic impact.

A fourth factor relates to the social impact of the forum. Our findings show that the social impact in Uden was stronger compared with Amersfoort. The municipality of Uden, which is an amalgamation of Uden and a number of surrounding villages, is characterized by solid community networks. The strength of the existing civil society and the connection with previous citizen initiatives seem to have contributed to the G1000's social impact. This 
suggests that communities with strong existing networks will be better able to create social impact as a result of deliberation.

A fifth and final factor is the interaction between the actors involved. Our analysis shows that politicians struggle to find new ways of interacting with citizens. They often want to stimulate innovative forms of citizen participation, but, at the same time, are hesitant about or even aversive to giving power to citizens. Whether ideas for new forms of participation and deliberation find their way into politics (political conceptual impact) and in the community (social conceptual impact) very much depends on the interaction between politicians and civil servants on one hand and active citizens on the other. It is the willingness of the first group to hand over power and responsibilities, and to make this more than a short-term experiment, which ultimately sets innovation in motion.

\section{Conclusion}

In contrast to other studies on deliberative forums, which often focus on the internal aspects of deliberation, we have looked at what happens after deliberation has taken place. We explicitly chose to concentrate on macro-effects, which meant disregarding many other forms of impact (see, for example, Goodin \& Dryzek, 2006). For this purpose, we developed a framework to systematically assess the impact of deliberative forums. As the cases of Amersfoort and Uden show, this framework helps to differentiate six types of impact. On the basis of this first empirical exploration, we argue that it can be used to assess other deliberative forums as well. Our framework and analysis are only a first step, as we acknowledge that more research is needed to understand the actual impact of deliberative forums. Based on our discussion of the literature and the findings from the two cases, we identified a number of mediating factors that can be helpful to provide a deeper understanding of this impact.

In our view, issues such as how to increase the impact of deliberative forums and how to connect these to the political and social public sphere deserve more scholarly attention. These questions relate to an emerging literature on scaling up mini-publics, central to which is the notion that it is vital for deliberative forums to have an impact outside the forum, in the broader public sphere (Curato \& Böker, 2016; Niemeyer, 2014). If deliberative democracy could indeed offer a possible remedy for declining levels of satisfaction with the institutions and processes of representative democracy, it must be seen to have substantive and durable effects. Otherwise, deliberative forums such as the G1000s may, at best, remain interesting experiments with little significance for democracy. 


\section{Declaration of Conflicting Interests}

The author(s) declared no potential conflicts of interest with respect to the research, authorship, and/or publication of this article.

\section{Funding}

The author(s) received no financial support for the research, authorship, and/or publication of this article.

\section{ORCID iD}

Harmen Binnema iD https://orcid.org/0000-0002-6889-8422

\section{References}

Bekkers, V., Fenger, M., Homburg, V., \& Putters, K. (2004). Doorwerking van strategische beleidsadvisering [The impact of strategic policy advice]. Rotterdam, The Netherlands: Erasmus Universiteit Rotterdam.

Bryson, J., Quick, K., Schively Slotterback, C., \& Crosby, B. (2013). Designing public participation processes. Public Administration Review, 73, 23-34.

Cain, B. E., Dalton, R. J., \& Scarrow, S. E. (2006). Democracy transformed? Expanding political opportunities in advanced industrial democracies. Oxford, UK: Oxford University Press.

Caluwaerts, D., \& Reuchamps, M. (2016). Generating democratic legitimacy through deliberative innovations: The role of embeddedness and disruptiveness. Representation, 52, 13-27.

Curato, N., \& Böker, M. (2016). Linking mini-publics to the deliberative system: A research agenda. Policy Science, 49, 173-190.

Dalton, R. J. (2014). Citizen politics: Public opinion and political parties in advanced industrial democracies. Washington, DC: CQ Press.

Ercan, S. A., \& Hendriks, C. M. (2013). The democratic challenges and potential of localism: Insights from deliberative democracy. Policy Studies, 34, 422-440.

Flynn, B. (2009). Planning cells and citizen juries in environmental policy: Deliberation and its limits. In F. Coenen (Ed.), Public participation and better environmental decisions: The promise and limits of participatory processes (pp. 57-71). Dordrecht, The Netherlands: Springer.

Font, J., \& Blanco, I. (2007). Procedural legitimacy and political trust: The case of citizen juries in Spain. European Journal of Political Research, 46, 557-589.

Font, J., Smith, G., Galais, C., \& Alarcon, P. (2015, July 1-4). Explaining the different fate of participatory policy proposals. Paper presented at the International Conference on Public Policy, Milan, Italy.

Fung, A. (2006). Varieties of participation in complex governance. Public Administration Review, 66, 66-75.

Fung, A. (2015). Putting the public back into governance: The challenges of citizen participation and its future. Public Administration Review, 75, 513-522. 
G1000. (2012). Final report: Democratic innovation in practice. Brussels, Belgium: G1000.

G1000 Uden. (2014). Vitaal inwonersinitiatief: Van denken en dromen naar durven en doen [Vital citizen initiative: From thinking and dreaming to daring and doing]. Uden, The Netherland: Gemeente Uden.

Goodin, R., \& Dryzek, J. (2006). Deliberative impacts: The macro-political uptake of mini-publics. Politics \& Society, 34, 219-244.

Grönlund, K., Bächtiger, A., \& Setälä, M. (2014). Deliberative mini-publics: Involving citizens in the democratic process. Colchester, UK: ECPR Press.

Hendriks, C. M. (2016). Coupling citizens and elites in deliberative systems: The role of institutional design. European Journal of Political Research, 55, 43-60.

Hibbing, J. R., \& Theiss-Morse, E. (1998). Too much of a good thing: More representative is not necessarily better. Political Science and Politics, 31, 28-31.

Hoppe, R. (2011). Institutional constraints and practical problems in deliberative and participatory policy making. Policy \& Politics, 39, 163-186.

Inglehart, R., \& Welzel, C. (2005). Modernization, cultural change and democracy: The human development sequence. Cambridge, UK: Cambridge University Press.

Kaase, M., \& Newton, K. (1995). Beliefs in government. New York, NY: Oxford University Press.

Michels, A. (2011). Innovations in democratic governance: How does citizen participation contribute to a better democracy? International Review of Administrative Sciences, 77, 275-293.

Nabatchi, N. (2010). Addressing the citizenship and democratic deficits: The potential of deliberative democracy for public administration. American Review of Public Administration, 40, 376-399.

Niemeyer, S. (2014). Scaling up deliberation to mass publics: Harnessing mini-publics in a deliberative system. In K. Grönlund, A. Bächtiger, \& M. Setälä (Eds.), Deliberative mini-publics: Involving citizens in the democratic process (pp. 177202). Colchester, UK: ECPR Press.

Olsen, E. D. H., \& Trenz, H.-J. (2016). The micro-macro link in deliberative polling: Science or politics? Critical Review of International Social and Political Philosophy, 19, 662-679.

Pogrebinschi, T., \& Ryan, M. (2017). Moving beyond input legitimacy: When do democratic innovations affect policy making? European Journal of Political Research, 57, 135-152. doi:10.1111/1475-6765.12219

Putnam, R. (2000). Bowling alone: The collapse and revival of American community. New York, NY: Simon \& Schuster.

Ryan, M., \& Smith, G. (2014). Defining mini-publics. In K. Grönlund, A. Bächtiger, \& M. Setälä (Eds.), Deliberative mini-publics. involving citizens in the democratic process (pp. 9-26). Colchester, UK: ECPR Press.

Skocpol, T. (2003). Diminished democracy: From membership to management in American civic life. Norman: University of Oklahoma Press.

Smith, G. (2009). Democratic innovations: Designing institutions for citizen participation. Cambridge, UK: Cambridge University Press. 
Stone, D. (2011). Policy paradox: The art of political decision-making. New York, NY: W. W. Norton.

Strandberg, K. (2015). Designing for democracy? An experimental study comparing the outcomes of citizen discussions in online forums with those of online discussions in a forum designed according to deliberative principles. European Political Science Review, 7, 451-474.

Tahvilzadeh, N. (2015). Understanding participatory governance arrangements in urban politics: Idealist and cynical perspectives on the politics of citizen dialogues in Göteborg, Sweden. Urban Research \& Practice, 8, 238-254.

Van der Kolk, H. (2008). Kiezen voor een nieuw kiesstelsel [Choosing a new electoral system]. Enschede, The Netherlands: Universiteit Twente.

Van Reybrouck, D. (2013). Tegen verkiezingen [Against elections]. Amsterdam, The Netherlands: De Bezige Bij.

\section{Author Biographies}

Ank Michels is an assistant professor at Utrecht University School of Governance. Her research interests include new forms of democracy and governance, citizen participation, and deliberation. She has published in journals such as Local Government Studies, International Review of Administrative Sciences, and International Journal of Public Administration, and in various edited volumes.

Harmen Binnema is an assistant professor at Utrecht University School of Governance. His research interests include political parties, local democracy and elections, intermunicipal cooperation, and citizen participation. He has published in Electoral Studies and in various Dutch journals and edited volumes. 